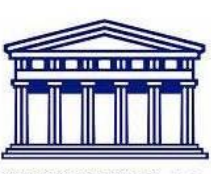

UNIVERSITY of the WESTERN CAPE

\title{
Pinpointing areas of increased soil erosion risk following land cover change in the Lake Manyara catchment, Tanzania
}

Maarten Wynants, Henok Solomon, Patrick Ndakidemi and William H. Blake

\begin{abstract}
Lack of long-term scientific land cover and erosional data impedes the development of sustainable land management plans to tackle land degradation and soil erosion problems in Tanzania. Using Landsat imagery, almost three decades of land cover change in the Lake Manyara catchment (1988-2016) was reconstructed. Data highlight that the major land cover types are highly dynamic and that there is a net conversion of natural or semi-natural land cover towards agricultural uses. Specifically, the biggest net declining cover types were found to be 'bushland', 'seasonal grassland' and 'permanent savanna', which have reduced by $8.7,6.1$ and $3.5 \%$ respectively. In this context an erosion risk model, based on the 'Revised Universal Soil Loss Equation', was applied to evaluate how changing land cover has affected risk of surface soil erosion by water. Model outputs indicate that a lot of land conversion has occurred in areas that are naturally vulnerable due to topography, soil type and rainfall patterns, seriously increasing the soil erosion risk. The resulting output maps can be particularly useful in pinpointing potential areas of increased erosion risk underpinning targeted investigation and management action to support soil conservation for improved food and water security.
\end{abstract}

\section{Introduction}

Tanzania is currently experiencing rapid changes in terms of economy, policy (Ponte, 2002) and population structure (FAO, 2014). However, there is concern that the socio-ecological responses to these changes are resulting into unsustainable use of the environment and natural resources (Maitima et al., 2009; Muyungi, 2007; Tengberg and Stocking, 1997). An ever increasing number of farmers are seeking land to establish agricultural operations, causing a marked shift from natural vegetation towards agricultural land (FAO, 2014; Gibbs et al., 2010). This scramble for land is pushing farmers to areas less suitable for agriculture, without infrastructure and on steep slopes (Jayne et al., 2014; Odgaard, 2002). Furthermore, the main fuel source in Tanzania is wood and charcoal, causing exploitation of forests and woodlands (Hiemstra-van der Horst and Hovorka, 2009). Finally, the livestock numbers have more than doubled in the last 50 years $(F A O, 2014)$, which combined with the reduced 
mobility of pastoralist communities is causing a massive increase in cattle densities on the pasture lands, leading to overgrazing and trampling of the soil (Little, 1996; Ruttan et al., 1999). The previous described land use changes and -pressures increase the vulnerability of the soil to erosion, which has a wide range of detrimental impacts (Pimentel, 2006; Thornes, 1990). First of all, the erosion mediated loss of soil and nutrients lowers the productivity of agricultural lands (Pimentel and Kounang, 1998), spiralling back to the agricultural production, food security and livelihoods of local people (Tengberg and Stocking, 1997). Second, the eroded soil causes siltation and eutrophication of river channels, lakes and reservoirs where they have a wide array of detrimental socio-economic and ecological impacts (Pimentel, 2006). Last of all, degradation of the unique Tanzanian ecosystems would be catastrophic for the biodiversity they harbour and ecosystem services they provide for the region (McClanahan and Young, 1996). Given that a large part of Tanzania's economy is based on wildlife viewing and ecotourism, ecosystem degradation may directly impact the livelihoods of millions of people (Christie et al., 2014; Kahyarara and Mchallo, 2008).

It is clear that economic and agricultural growth is essential to absorb the increasing population pressure in Tanzania, but at the same time that soil erosion driven by these pressures poses a major treat for the sustainability of this growth. There is a need for sustainable management plans to make sure development happens without compromising the soil- and water resource base (Lal, 2000; Maitima et al., 2009; Muyungi, 2007). However, the lack of long term scientific data about land cover change and erosion dynamics in Tanzania impedes the assessment of the sustainability of land use change. A possible solution to this issue can be the use of Landsat imagery to document the changes in land cover (Zhu and Woodcock, 2014). Vegetation is one of the most dynamic and anthropogenicallyimpacted factors controlling soil erosion (Thornes, 1990). However, the extent and impact of vegetation changes on the soil erosion dynamics depend on other less dynamic factors in the areas of change (Renard et al., 1997; Wischmeier and Smith, 1978). Hence, land cover reconstruction can form the base for erosion risk maps together with slope, soil and precipitation data (Leh et al., 2013; Vrieling, 2006). In this context, the goal of this study is to pinpoint locations for targeted land management interventions in order to combat soil erosion and land degradation, as well as safeguard food security, biodiversity and local livelihoods. In this contribution, we provide a new step-by-step methodology developed for assessing changes in surface erosion risk due to land cover changes in the Lake Manyara catchment. The observed changes and modelled results are discussed in their social, economic and environmental setting with attention to limitations and wider potential applications of this methodology. Herein we aim to provide a template for assessing changes in land cover- and surface erosion risk over the past decades in sub-Saharan Africa and other areas where there is lack of long-term land cover or soil erosion monitoring schemes. 


\section{Material and methods}

All the input data and model outputs can be accessed online for reproductive purposes (Wynants, 2018).

\subsection{Study site}

The Lake Manyara area in the East African Rift System (EARS) region of Tanzania is characterised by distinct volcanic and tectonic topography and a high environmental diversity (African Wildlife Foundation, 2003; Deus et al., 2013). It is also considered to be an important driver for development in northern Tanzania in terms of ecotourism, conservation, fisheries, (irrigation) agriculture and pastoralism. However, increasing socio-economic pressures impose serious threats for the ecosystem services needed to support its status as a system of high value (African Wildlife Foundation, 2003; Muyungi, 2007; Ngana et al., 2004). The environmental diversity of the system together with the typical East-African pressures makes this system an ideal natural laboratory in which to study soil erosion problems of the EARS. The exact Lake Manyara watershed was delineated using Digital Elevation Maps (DEMs) of the area (Farr et al., 2007) and the 'Catchment Area', 'Channel network' and 'Watershed basins' tools in QGIS 2.14.8, following the hydrological analysis protocol (Olaya et al., 2014). Fig. 1 shows the resulting detailed delineation of the total Lake Manyara catchment area and its location in Africa.

\subsection{Land cover classification}

Ortho-rectified and geometrically corrected Landsat images were obtained from USGS Earth Explorer and selected on the lack of interfering cloud cover. To highlight the effect of seasonal drying on vegetation, which is important regarding soil erosion dynamics (Kirkby, 1980), high quality images at the end of the dry season from two time periods were used. For the recent land cover we used 'Landsat 8' files obtained on 22/10/2016 (east) and 16/02/2016 (west), while for the historic land cover we used 'Landsat 4-5' files obtained on 01-10-1988 (east) and 15/02/1987 (west). These dates allowed us reconstruct almost three decades of land cover change in the area. During multiple ground-truthing campaigns, a comprehensive documentation of the land cover spectrum was attempted using geo-tagged photos and field notes. The efforts focused close to accessible roads with additional on foot surveys in more remote areas. Overall with the knowledge gained from these campaigns, coupled with the available high resolution satellite imagery from Google Earth, sufficient information was available to delineate the major land cover types in the area and build signature files. These are prior land cover delineated areas representative for the catchment. The conversion of the Landsat imagery to a land cover classification was done using the supervised method in ArcMap, which is based on these expert-build signature files. However, the biggest challenge with classifying the 1988 Landsat imagery was a lack of information on land cover or high resolution imagery for that period. The key solution for this was to select signature files with land cover delineation in areas 
where we more or less knew the land cover had remained stable (National parks, reserves, etc.) and/or to select areas where the land cover in 1988 could be predicted with a high certainty (distinct land cover areas). To guarantee the most detailed classification, the land cover was split up into 23 groups, which could in turn be grouped into 11 major classes (Table 1). Even with the high amount of land cover classes, false classifications were unavoidable due to reflectance differences in the same cover type, which can be caused by other factors such as soil type or wetness. Vice versa, different cover types are potentially classified as one because of reflectance similarities. The last step in the land cover reconstruction was to visually detect and correct those false classifications, which was done by manually selecting the incorrect areas and giving them the right land cover class. Additionally the limited cloud cover classifications were replaced with the dominant surrounding land cover. Land cover change analysis was performed following Pontius et al. (2004), accounting for the gross changes, net changes, persistence and swap.

\subsection{Erosion risk mapping and comparison}

Erosion risk modelling was performed using ArcGIS' 'modelbuilder' and is based on the Revised Universal Soil Loss Equation (Renard et al., 1997; Wischmeier and Smith, 1978), which calculates the mean annual soil loss rates by sheet and rill erosion by following equation:

$E=R \times L S \times K \times C \times P$

Where $\mathrm{E}$ : annual average soil loss $\left(\mathrm{t} \mathrm{ha}^{-1} \mathrm{yr}^{-1}\right), \mathrm{R}$ : rainfall erosivity factor (MJ $\mathrm{mm} \mathrm{ha} \mathrm{h}^{-1} \mathrm{~h}^{-\mathbf{1}} \mathrm{yr}^{-1}$ ), $\mathrm{K}$ : $\quad$ soil erodibility factor ( $\mathrm{t}$ ha $\mathrm{h} \mathrm{ha}^{-1} \mathrm{MJ}^{-1}$ $\mathrm{mm}^{-1}$ ), C: cover-management factor (dimensionless), LS: slope length and slope steepness factor (dimensionless), and P: support practices factor (dimensionless). The slope factor (LS) is a proxy for the soil erosion vulnerability of an area regarding the slope angle and length and its distribution in the catchment is shown in Fig. 2a. For the calculation of LS in ArcGIS from the DEM (Farr et al., 2007) we used the LS-tool developed by Zhang et al. (2013), which is based on McCool et al. (1989) and Desmet and Govers (1996): 


$$
\begin{aligned}
& L S=L \times S \\
& L_{i j-i n}=\frac{\left[\left(A_{i j-i n}+D^{2}\right)^{m+1}-\left(A_{i j-i n}\right)^{m+1}\right.}{\left(D^{m+2}\right) \times\left(x_{i j}^{m}\right) \times(22.13)^{m}} \\
& m=\frac{\beta}{1+\beta} \\
& \beta=\frac{(\sin \theta)}{\left[3 \times(\sin \theta)^{0.8}+0.56\right]} \\
& S=10.8 \times \sin \theta+0.03 \text { if } \theta<9 \% \\
& S=16.8 \times \sin \theta-0.05 \text { if } \theta>9 \%
\end{aligned}
$$

Where: $\mathrm{m}$ is the variable length-slope exponent,? ? is the ratio of rill vs. inter-rill erosion,? ? is the slope angle, $A_{i j}-i n$ is the contributing area at the inlet of the grid cell with coordinates $(\mathrm{i}, \mathrm{j})$ in $\mathrm{m}^{2}, \mathrm{D}=\operatorname{grid}$ cell size $(\mathrm{m})$ and $\mathrm{X}_{\mathrm{ij}}=\left(\sin \alpha_{\mathrm{ij}}+\cos \alpha_{\mathrm{ij}}\right)$. Flow accumulation was used as a proxy representing the contributing area for each cell (A). A threshold unit of $100000 \mathrm{~m}^{2}$ was inserted as the point where flow accumulates into the river network and changes from hillslope surface erosion to riverine- or gully erosion. 

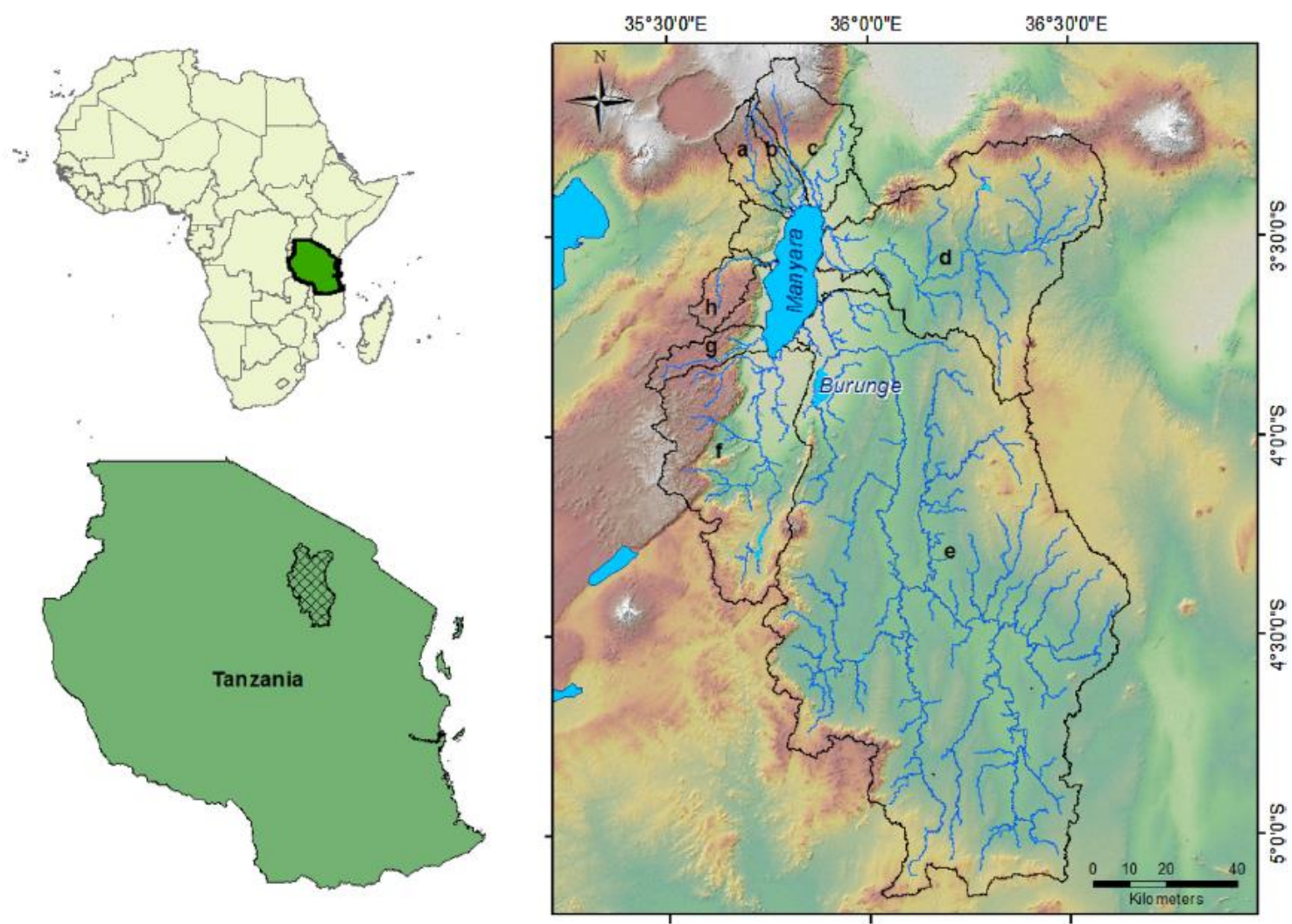

Fig. 1. Elevation map of the Lake Manyara catchment, located in Tanzania, with its major sub-basins and their river systems flowing towards the lake: a) Marera, b) Kirurumo, c) Mto Wa Mbu-Simba, d) Makuyuni, e) Tarangire, f) Dudumera, g) Magara and h) Endabash.

Table 1

The selected land cover types, their broader classification and corresponding C-factor scores (bold).

\begin{tabular}{lllll}
\hline Land cover type & Broad type & C-factor & Land cover type & Broad type \\
\hline Highland forest & Forest & 0.05 & Afroalpine grassland & Permanent savanna \\
Lowland forest & Forest & 0.05 & Seasonal grassland & Seasonal grassland \\
Riverine forest & Forest & 0.05 & Saline grassland & Saline grassland \\
Seasonal agriculture & Agriculture & Wetland vegetation & Wetland/Riparian veg. \\
Highland agriculture & Agriculture & Lake delta & Wetland/Riparian veg. \\
Grassy agriculture & Agriculture & 0.35 & Riparian vegetation & Wetland/Riparian veg. \\
Irrigation agriculture & Irrigation & 0.40 & Burned savanna & Permanent savanna \\
Bare agriculture & Agriculture & 0.25 & Degraded & Bare \\
Mosaic & Mosaic & 0.60 & Bare & Bare \\
Bushland & Bushland & 0.20 & Mud- and salt flats & Water bodies \\
Permanent savanna & Permanent savanna & 0.15 & Water bodies & Water bodies \\
Floodplain grassland & Permanent savanna & 0.20 & Clouds & Surrounding cover \\
\hline
\end{tabular}

In terms of rainfall erosivity, the intensity and frequency of high intensity rainfall events are more predictive than the total rainfall amount. However, this information was not available for our study site. For East-Africa, however, there is a high correlation between the Kinetic energy of the high intensity storms and the mean annual precipitation, as almost all rainfall in the area happens in seasonal intensive events (Moore, 1979). The mean annual rainfall (MAR) data was obtained from the global "CHELSA" dataset (Karger et al., 2017), which is based on 34-year of climate data (1979-2013) combined with numerous other predictive inputs. Using Moore's (1979) regressions, the kinetic energy of the rains (KE) and ultimately the rainfall erosivity factor (R) was calculated and is shown in Fig. 2 b. 
$K E=3.96 \times M A R+3122$

$R=17.02(0.029 \times K E-26.0)$

The soil erodibility factor was calculated from soil information obtained from the Harmonized world soil database (Nachtergaele et al., 2008), complemented with field information regarding soil texture, and organic carbon content. With that information the basin was divided into 16 different soil regions, which could be split into 5 textural classes for the basin: Heavy clay, Clay, Clay loam, Sandy clay loam and Loam. Together with the topsoil organic carbon content (\% of weight) of each region, this information was used to calculate the soil erodibility factor (Fig. 2c) following the simplified table of Stewart et al. (1975), accounting for the conversion to SI units by multiplying with 0.1317 .

The cover-management factor reflects the effects of plant- and root cover and soil disturbing activities, which are included when giving the erosion vulnerability scores of different cover types (Wischmeier and Smith, 1978). It was opted to include the support practice factor in the cover-management factor.
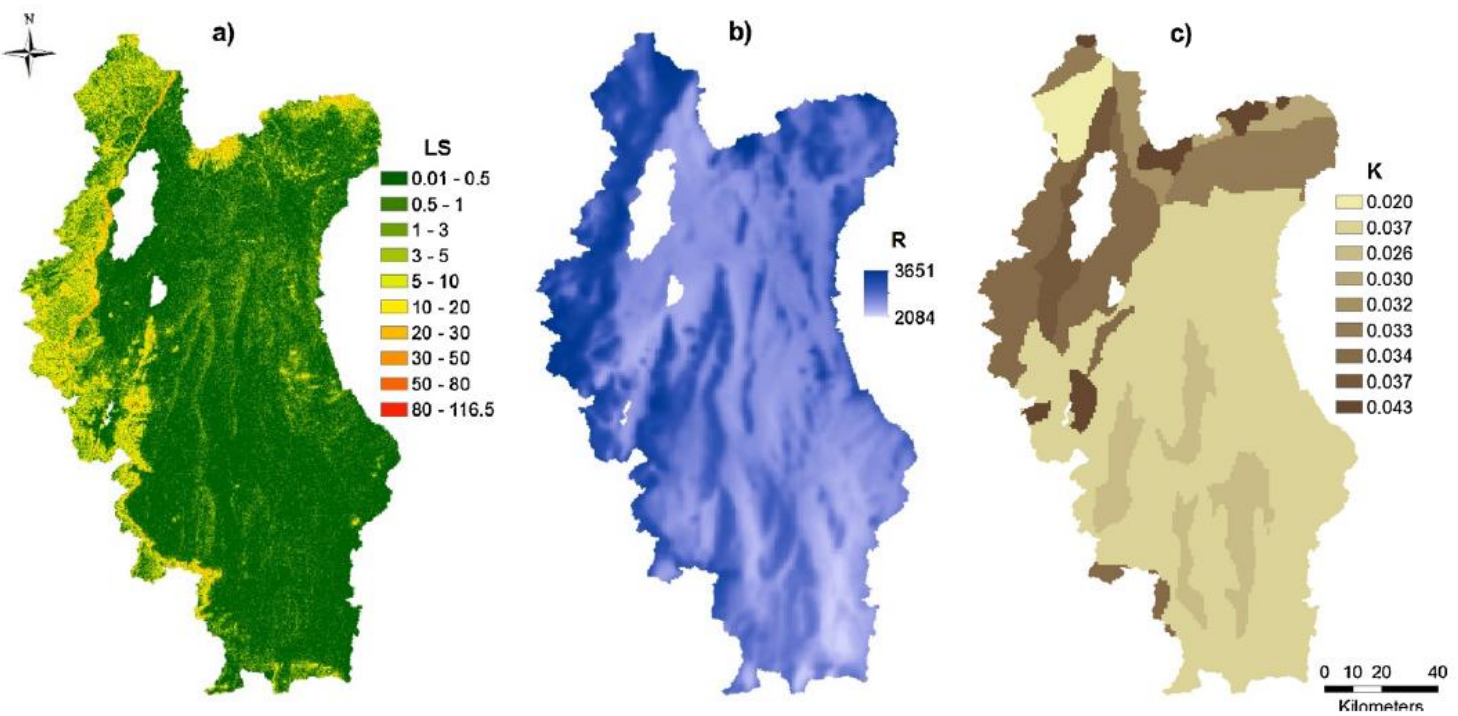

Fig. 2. The model input maps of the a) dimensionless slope length and slope steepness factor LS, b) Rainfall erosivity factor R (in MJ mm ha ${ }^{-1} \mathrm{~h}^{-1} \mathrm{yr}^{-1}$ ), and c) Soil erodibility factor $\mathrm{K}$ (in $\mathrm{tha} \mathrm{h} \mathrm{ha}^{-1} \mathrm{MJ}^{-1} \mathrm{~mm}^{-1}$ ). 


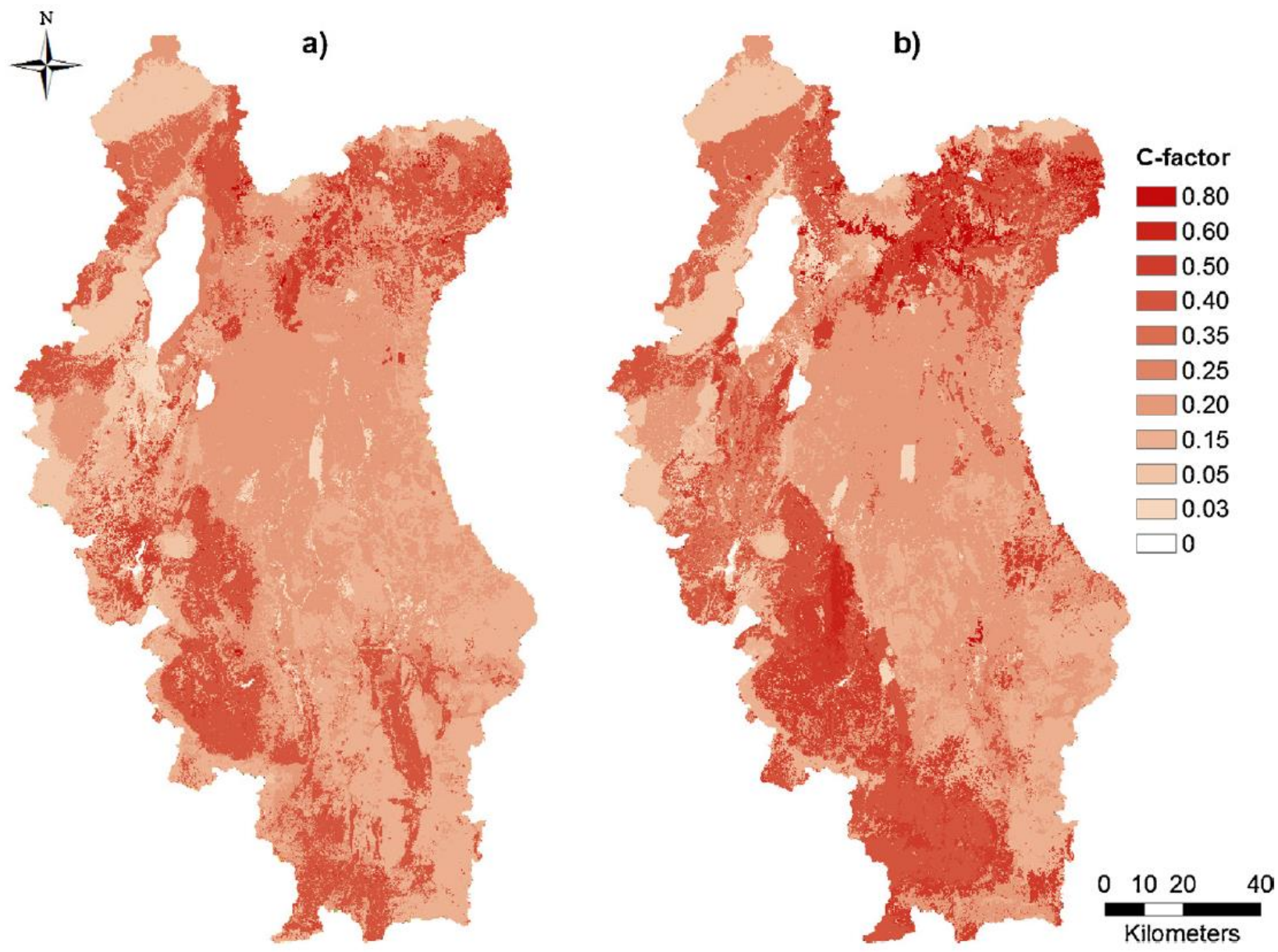

Fig. 3. The dimensionless land cover erosivity factor input maps for a) 1988 and b) 2016 .

The risk scores per land cover type (displayed in Table 1) were chosen following field observations (Blake et al., 2018) and literature examples (Angima et al., 2003; Ligonja and Shrestha, 2015; Panagos et al., 2015; Renard et al., 1997). By giving each land cover type a cover-management score, maps of the C-factor were created for both 1988 (Fig. 3a) and 2016 (Fig. 3b). All of the previously described factor maps were subsequently used as input parameters for the RUSLE modelling and the resulting output provide an estimation of the annual soil loss rates by sheet and rill erosion in the Lake Manyara basin in 1988 (Error! Reference source not found.a) and 2016 (Error! Reference source not found.b). However, the ultimate goal of this study was not to estimate the soil loss quantities in the catchment, but to map the on-site changes in soil erosion risk. By subtracting the map of 2016 ( $\mathrm{E}_{2016)}$ with that of 1988 ( $\mathrm{E}_{1988}$ ), a risk change map ( $\Delta \mathrm{E}$, Fig. 5c) was obtained, which shows the spatial distribution of erosion risk increases and decreases in the Manyara catchment:

$\Delta E=E_{2016}-E_{1988}$ 


\subsection{Land cover validation and model sensitivity analysis}

The land cover classification was validated by stratified randomised sampling, where the output raster was overlaid with 300 points, evenly spread per land cover class. For each point the classified cover type was checked with high resolution Google Earth images. Three possible validation types were possible: 'Correct', 'False' and 'Grey' because in some cases the actual cover was in an intermediate zone (for example between 'permanent savanna' and 'bushland'). Subsequently, a sensitivity analysis was performed to test the model's response to potential omission or commission errors in the model inputs. Following the literature description of the model input errors (Farr et al., 2007; Karger et al., 2017; Nachtergaele et al., 2008), it was decided to test the model's sensitivity for a $10 \%$ potential error to the slope-, soil- and precipitation data. This was done by creating a random raster with values ranging from 0.9 to 1.1 and multiplying it with the selected model parameter, while keeping the other parameters constant. For the sensitivity analysis to land cover errors, the results of the land cover validation was used. A raster was created, where the percentage of land cover found to be correctly classified was randomly translated to a percentage of cells given the value 0 , the percentage of land cover found to be grey was randomly translated to a percentage of cells and given a value ranging from -0.05 to 0.05 (as the errors are minor), and the percentage of land cover found to be classified falsely was randomly translated to a percentage of cells given a value ranging between -0.30 to 0.30 (as the errors are major). The resulting sensitivity analysed model outputs were subsequently compared with each other to assess the potential impact of errors on the results.

\section{Results and discussion}

\subsection{Land cover changes}

The land cover changes are summarized visually in Fig. 4 and numerically in Table 2. The cross-tabulation with absolute values can be found in annex 1 and gives information about persistence and area of specific land cover types which are converted to others. The most distinctive trends are the net decreases in 'bushland', 'permanent savanna' and 'seasonal grassland', which would be traditionally used as common grazing areas for pastoralist. At the same time substantial net increases in 'Agriculture' and 'Irrigation' and a minor increase in 'Mosaic' can be observed. Another alarming shift is the substantial net increase in 'bare/degraded land', which is mostly limited to the Makuyuni subcatchment and is largely caused by degradation of grazing lands. This development highlights the negative spiral of land degradation, as these bare lands will be even more vulnerable to soil erosion, hence degrade further. Other notable trends are the decrease in wetland coverage and the slight increase in 'forest' cover, the first being converted among others to irrigation agriculture and grazing areas and the latter probably due to a better protection of the forest reserves. The decrease in saline grassland is linked to the increase in the area of water bodies, which are dynamic and engulf parts of their surroundings in wet periods. 
Even though the net changes are already very distinct, the gross changes and swap between the different land cover types are much higher, indicating that the system is highly dynamic and that some land cover types have a low persistence. The highest percentages of swap are found between 'Permanent Savanna', 'Bushland' and 'Seasonal grassland', which besides losing area to agriculture also shift between each other. However, the drivers behind previously described net and gross changes are not straightforward. Land cover change is driven by both environmental- and land use change, the latter in term is a result of complex social, political and economic transitions (Blake et al., 2018; Rohde and Hilhorst, 2001).

Validation of the recent land cover classification described $89 \%$ of the random points as' correct', $7 \%$ as 'grey' and $4 \%$ as 'false'. However, the accuracy of the classification differed between the classes and are summarised in Appendix 2. These results indicate that the land cover reconstruction methodology has a relatively high level of accuracy and is representative of the actual land cover dynamics in the Lake Manyara catchment.

\subsection{Erosion risk change}

Analysis of the spatial distribution of the erosion risk changes implies that there is no ubiquitous increase in erosion risk and there are also substantial areas showing risk decrease (Fig. 5c). Over the entire catchment there is nonetheless a domination of increasing risk zones, which are grouped in spatially distinct areas representing erosion hotspots. Results indicate that a lot of the land conversion is happening in natural high risk areas, giving rise to spatially distinct areas of anthropogenicallyenhanced surface erosion risk. This fits with the dominating research, stating that the effect of land cover change on soil erosion dynamics is highly dependent on the environment where the change occurs (Foley et al., 2005; Montgomery, 2007). Most of the protected areas are characterized by stable or decreasing erosion risk, highlighting the importance of land management (Appendix 3). 

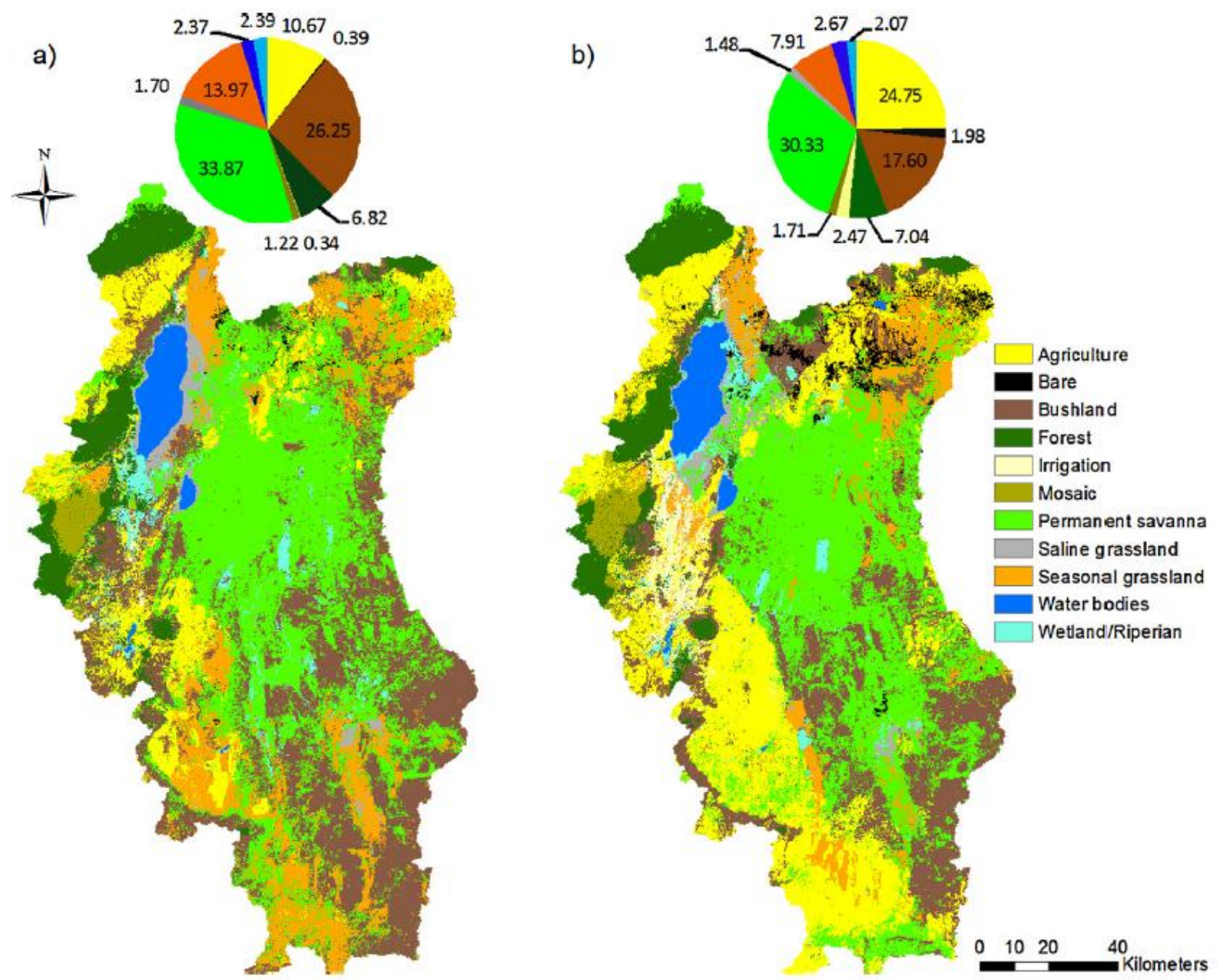

Fig. 4. Land cover maps and percentages of land cover types derived from Landsat imagery of a) 1988 and b) 2016. 

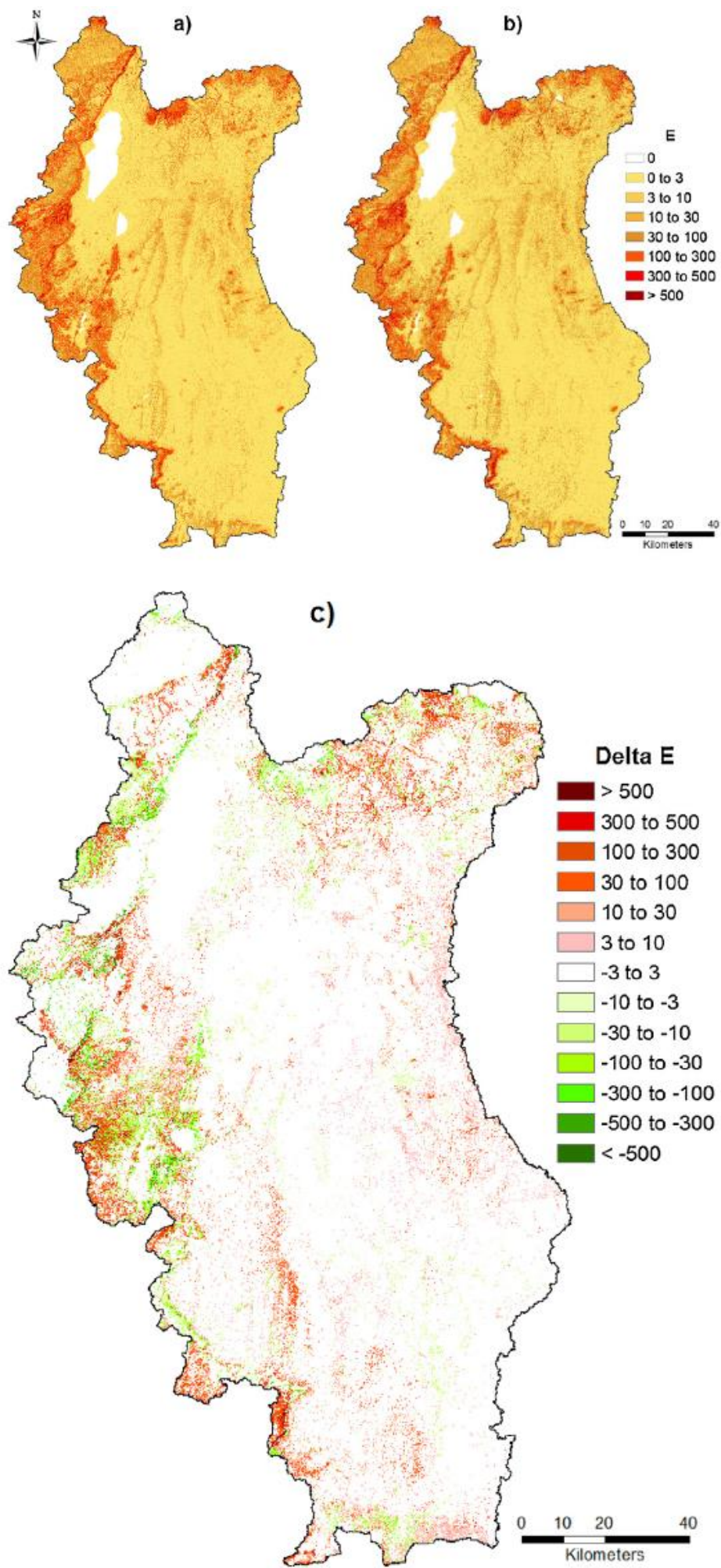

Fig. 5. Modelled output maps of the annual average soil loss $\mathrm{E}$ (in t ha-1 yr-1 or as qualitative proxy for erosion risk) for a) 1988 and b) 2016 . With c) the predicted changes in erosion risk (Delta E) following land conversion between 1988 and 2016. In the green areas erosion risk has decreased, while in the red areas it has increased. 
Percentages of the total catchment area $\left(18372 \mathrm{~km}^{2}\right)$ per land cover type in 1988 and 2016, the total gains, losses, gross changes, swap and net changes (- values have

\begin{tabular}{|c|c|c|c|c|c|c|c|}
\hline & $\% 1988$ & $\% 2016$ & $\%$ Gain & $\%$ Loss & $\%$ Gross change & $\%$ Swap & $\%$ Net change \\
\hline Agriculture & 10.7 & 24.8 & 16.7 & 2.6 & 19.4 & 5.3 & 14.1 \\
\hline Bare/Degraded & 0.4 & 2.0 & 1.8 & 0.2 & 2.0 & 0.4 & 1.6 \\
\hline Bushland & 26.2 & 17.6 & 6.4 & 15.1 & 21.5 & 12.8 & -8.6 \\
\hline Forest & 6.8 & 7.0 & 1.4 & 1.1 & 2.5 & 2.3 & 0.2 \\
\hline Irrigation & 0.3 & 2.5 & 2.3 & 0.1 & 2.4 & 0.3 & 2.1 \\
\hline Mosaic & 1.2 & 1.7 & 0.7 & 0.2 & 0.9 & 0.5 & 0.5 \\
\hline Permanent savanna & 33.9 & 30.3 & 10.9 & 14.4 & 25.3 & 21.7 & -3.5 \\
\hline Saline grassland & 1.7 & 1.5 & 0.8 & 1.0 & 1.9 & 1.6 & -0.2 \\
\hline Seasonal grassland & 14.0 & 7.9 & 3.9 & 9.9 & 13.8 & 7.7 & -6.1 \\
\hline Water bodies & 2.4 & 2.7 & 0.3 & 0.0 & 0.4 & 0.1 & 0.3 \\
\hline Wetland/Riparian & 2.4 & 2.1 & 1.6 & 1.9 & 3.6 & 3.2 & -0.3 \\
\hline
\end{tabular}

Sensitivity analysis suggests that introducing errors in the separate factors had minor effects on the eventual quantitative predictions of the surface soil erosion risks, mostly affecting the outlier values. Regarding the spatial distribution of risk change, there was no observable effect when introducing error in any of the model inputs (Appendix 4). In conclusion, introducing errors in the model parameters thus only led to minor changes in the quantitative predictions and the spatial distribution of erosion hotspot zones remained similar. This observation is particularly promising, as the main goal of this study is to pinpoint hotspots of increased erosion risk.

\subsection{Limitations and possibilities}

There are numerous limitations with risk change modelling based on RUSLE and remotely sensed data (Claessens et al., 2008; Sepuru and Dube, 2018; Vrieling, 2006). One of these is the focus on surface erosion (interrill and rill erosion), and not accounting for other forms of erosion (e.g. streamline incision processes), which could be potential contributors to net soil export and land degradation in the Manyara catchment (Blake et al., 2018). It is thus important to acknowledge that this modelling only represents one aspect of the total soil erosion spectrum. Possibilities lie in the coupling of these models with models mapping vulnerability to other erosion processes (e.g. mass movements, gully-, riverine- and wind erosion), which would give a better representation of the total erosion vulnerability (Aksoy and Kavvas, 2005). Another issue is that the erosion risk model is limited to predict on-site changes to vulnerability of soil erosion but is not suitable for studying catchment wide source-to-sink dynamics and hence overall delivery of material from a given area. Additionally, these risk maps do not account for sediment supply limitation and overland flow initiation dynamics, which are important factors for erosion dynamics as well. Combining this modelling approach with sediment tracing techniques is particularly promising as these can provide detailed information of source-to-sink dynamics in the catchment and confirm the proportional contribution (changes) of areas of high risk, thus validating the model (Owens et al., 2016). Further, the resolution of the data $(30 \mathrm{~m}$ ) excludes the effects of microtopographic landforms such as terraces, which divide the hillslope in small plateaus and so decreases the slope angle and length. Moreover, the scoring process 
of land cover types arguably lacks the complex interaction of land cover with erosion. For example, overgrazing and trampling of rangelands due to overstocking would increase in erosion risk even though land cover remained stable. Another limitation in semi-arid areas is that the rainfall erosivity is based on the mean annual precipitation of a 30 year period and does not consider the potential effects of interannual variation in precipitation. This variability in rainfall is also tightly linked to vegetation dynamics, where a wet year following a dry year can create an extra high vulnerability of soil erosion, as the vegetation has desiccated and the C- factor would be higher (Kirkby, 1980). Last of all, Landsat images only can go back a couple of decades in time, which is not a very tangible baseline in the Lake Manyara area. Possibilities to extend the period of land cover reconstruction by using old colonial aerial photographs would permit assessment of baseline conditions to a transformative historic event such as the end of the Colonial period.

\section{Conclusions}

The land cover reconstruction approach to soil erosion risk assessment presented here provides an important framework within which to assess changing soil erosion risk to support land management decisions. Evaluation of land cover data in the present study offers strong evidence of large-scale conversion from natural or semi-natural cover to agricultural land. Much of this land conversion is happening in naturally vulnerable areas, giving rise to notable increases in erosion risk. Quantitative estimation of soil loss can be a useful tool in smaller agricultural catchments but is less relevant for larger and diverse catchment such as Lake Manyara. In this regard, the strength of this approach lies in its mapping output, which provides a spatially qualitative proxy of erosion risk changes following land conversion. This information is particularly useful to pinpoint hotspot areas of increased risk which (1) support targeting these areas for more detailed investigation of controls on erosion processes and (2) guide stakeholders and policy makers in land management decisions of soil conservation measures and possible action.

\section{Acknowledgments}

This work was carried out as part of a PhD project funded by Plymouth University with support from European Commission (Horizon 2020 IMIXSED project ID 644,320) and RCUK GCRF project NE/ P015603/1. Additional funding was received through the North South South cooperation project 'Balancing water for biodiversity and socio-economic use in a changing climate.' funded by VLIRUOS and co-ordinated by Professor Luc Brendonck. The authors would also like to extend their gratitude to the Nelson Mandela Institution for Science and Technology in Arusha, Tanzania for their hospitality and assistance during field work. Furthermore, the authors would like to thank Professor Ralph Fyfe and Mr Shaun Lewin from the GeoMapping unit of Plymouth University for their constructive criticism and invaluable assistance in model implementation. Last of all, the 
authors would like to thank the reviewer for the constructive criticism and suggestions, which improved the quality of the paper significantly.

\section{Appendix A. Supplementary data}

Supplementary material related to this article can be found, in the online version, at doi:https://doi.org/10.1016/j.jag.2018.05.008. 


\section{References}

African Wildlife Foundation, 2003. Lake Manyara Watershed Assessment: Progress

Report. African Wildlife foundation p. 27.

Aksoy, H., Kavvas, M.L., 2005. A review of hillslope and watershed scale erosion and sediment transport models. Catena 64, 247-271.

Angima, S.D., Stott, D.E., O’Neill, M.K., Ong, C.K., Weesies, G.A., 2003. Soil erosion prediction using RUSLE for central Kenyan highland conditions. Agric. Ecosyst. Environ. 97, 295-308.

Blake, W.H., Rabinovich, A., Wynants, M., Kelly, C., Nasseri, M., Patrick, A., Gilvear, D., L., M., Mtei, K., Roberts, N., Wilson, G., Boeckx, P., Navas, A., H.G., S., Ndakidemi, P., 2018. Soil erosion challenges in the Global South: the need for an interdisciplinary approach. Manuscript in revision.

Christie, I., Christie, I.T., Fernandes, E., Messerli, H., Twining-Ward, L., 2014. Tourism in Africa: Harnessing Tourism for Growth and Improved Livelihoods. World Bank Publications.

Claessens, L., Van Breugel, P., Notenbaert, A., Herrero, M., Van De Steeg, J., 2008.

Mapping Potential Soil Erosion in East Africa Using the Universal Soil Loss Equation and secondary data, vol. 325. IAHS publication, pp. 398.

Desmet, P., Govers, G., 1996. A GIS procedure for automatically calculating the USLE LS factor on topographically complex landscape units. J. Soil Water Conserv. 51, 427-433.

Deus, D., Gloaguen, R., Krause, P., 2013. Water balance modeling in a semiarid en- vironment with limited in situ data using remote sensing in Lake Manyara, East African Rift, Tanzania. Remote Sens. 5, 1651-1680.

FAO, 2014. FAOSTAT Database Collections. FAO, Rome: Italy.

Farr, T.G., Rosen, P.A., Caro, E., Crippen, R., Duren, R., Hensley, S., Kobrick, M., Paller, M., Rodriguez, E., Roth, L., 2007. The shuttle radar topography mission. Rev. Geophys. 45.

Foley, J.A., DeFries, R., Asner, G.P., Barford, C., Bonan, G., Carpenter, S.R., Chapin, F.S., Coe, M.T., Daily, G.C., Gibbs, H.K., 2005. Global consequences of land use. Science 309, 570-574.

Gibbs, H.K., Ruesch, A.S., Achard, F., Clayton, M.K., Holmgren, P., Ramankutty, N., Foley,

J.A., 2010. Tropical forests were the primary sources of new agricultural land in the 1980 s and 1990s. Proc. Natl. Acad. Sci. U. S. A. 107, 16732-16737.

Hiemstra-van der Horst, G., Hovorka, A.J., 2009. Fuelwood: the "other" renewable energy source for Africa? Biomass Bioenergy 33, 1605-1616.

Jayne, T.S., Chapoto, A., Sitko, N., Nkonde, C., Muyanga, M., Chamberlin, J., 2014. Is the scramble for land in Africa foreclosing a smallholder agricultural expansion strategy? J. Int. Aff. 67, 35.

Kahyarara, G., Mchallo, I., 2008. The Strategic Environmental Assessment (SEA) of Tourism Development in the Northern Tourist Circuit of Tanzania. 
International Association for Impact Assessment, Centre for Environmental Economics and Development Research Retrieved March 2, 2009.

Karger, D.N., Conrad, O., Böhner, J., Kawohl, T., Kreft, H., Soria-Auza, R.W., Zimmermann, N.E., Linder, H.P., Kessler, M., 2017. Climatologies at high resolution for the earth's land surface areas. Sci. Data 4 sdata2017122.

Kirkby, M.J., 1980. The problem. In: Kirkby, M.J.a.M., R.P.C (Eds.), Soil Erosion. Wiley, Chichester, pp. 1-16.

Lal, R., 2000. Soil management in the developing countries. Soil Sci. 165, 5772.

Leh, M., Bajwa, S., Chaubey, I., 2013. Impact of land use change on erosion risk: an integrated remote sensing, geographic information system and modeling metho- dology. Land Degrad. Dev. 24, 409-421.

Ligonja, P.J., Shrestha, R.P., 2015. Soil erosion assessment in Kondoa eroded area in Tanzania using universal soil loss equation, geographic information systems and socioeconomic approach. Land Degrad. Dev. 26, 367-379.

Little, P.D., 1996. Pastoralism, biodiversity, and the shaping of savanna landscapes in East Africa. Africa 66, 37-51.

Maitima, J.M., Mugatha, S.M., Reid, R.S., Gachimbi, L.N., Majule, A., Lyaruu, H., Pomery,

D., Mathai, S., Mugisha, S., 2009. The linkages between land use change, land de-

gradation and biodiversity across East Africa. Afr. J. Environ. Sci. Technol. 3. McClanahan, T.R., Young, T.P., 1996. East African Ecosystems and their Conservation.

Oxford University Press on Demand.

McCool, D.K., Foster, G.R., Mutchler, C., Meyer, L., 1989. Revised slope length factor for the universal soil loss equation. Trans. ASAE 32, 1571-1576.

Montgomery, D.R., 2007. Soil erosion and agricultural sustainability. Proc. Natl. Acad.

Sci. U. S. A. 104, 13268-13272.

Moore, T.R., 1979. Rainfall erosivity in East-Africa. Geogr. Ann. A 61, 147-156. Muyungi, R., 2007. Managing Land Use, Protecting Land and Mitigating Land Degradation: Tanzania Case Study, Climate and Land Degradation. Springer, pp.

437-445.

Nachtergaele, F., van Velthuizen, H., Verelst, L., Batjes, N., Dijkshoorn, J., van Engelen, V., Fischer, G., Jones, A., Montanarella, L., Petri, M., 2008. Harmonized World Soil Database (Version 1.0). Food and Agric Organization of the UN (FAO); International Inst. for Applied Systems Analysis (IIASA); ISRICWorld Soil Information; Inst of Soil Science-Chinese Acad of Sciences (ISS-CAS); EC-Joint Research Centre (JRC).

Ngana, J., Mwalyosi, R., Yanda, P., Madulu, N., 2004. Strategic development plan for integrated water resources management in Lake Manyara sub-basin, North-Eastern Tanzania. Phys. Chem. Earth Parts A/B/C 29, 1219-1224. 
Odgaard, R., 2002. Scrambling for land in Tanzania: processes of formalisation and le-

gitimisation of land rights. Eur. J. Dev. Res. 14, 71-88.

Olaya, V., 2014. Hydrological analysis. In: Thiede, R., Sutton, T., Duster, H.,

Sutton, M. (Eds.), QGIS Training Manual, Release 2.2, pp. 485-495.

Owens, P., Blake, W., Gaspar, L., Gateuille, D., Koiter, A., Lobb, D., Petticrew, E.,

Reiffarth, D., Smith, H., Woodward, J., 2016. Fingerprinting and tracing the sources of soils and sediments: earth and ocean science, geoarchaeological, forensic, and human health applications. Earth-Sci. Rev. 162, 1-23.

Panagos, P., Borrelli, P., Meusburger, K., Alewell, C., Lugato, E., Montanarella, L., 2015.

Estimating the soil erosion cover-management factor at the European scale. Land Use Policy 48, 38-50.

Pimentel, D., 2006. Soil erosion: a food and environmental threat. Environ. Dev. Sustain.

8, 119-137.

Pimentel, D., Kounang, N., 1998. Ecology of soil erosion in ecosystems.

Ecosystems 1, 416-426.

Ponte, S., 2002. Farmers \& Markets in Tanzania: How Policy Reforms Affect

Rural Livelihoods in Africa. James Currey.

Pontius Jr, R.G., Shusas, E., McEachern, M., 2004. Detecting important categorical land

changes while accounting for persistence. Agric. Ecosyst. Environ. 101, 251268. Renard, K., Meyer, L., Foster, G., 1997. Predicting Soil Erosion by Water:

A Guide to

Conservation Planning With the Revised Universal Soil Loss Equation (RUSLE). U.S. Department of Agriculture.

Rohde, R., Hilhorst, T., 2001. A Profile of Environmental Change in the Lake Manyara

Basin, Tanzania. International Institute for Environment and Development, Drylands Programme.

Ruttan, L.M., Borgerhoff Mulder, M., Berkes, F., Colding, J., Folke, C., Fratkin, E., Galaty, J.G., Homewood, K., Little, P.D., Ostrom, E., 1999. Are East African pastoralists truly conservationists? Curr. Anthropol. 40, 621-652.

Sepuru, T.K., Dube, T., 2018. An appraisal on the progress of remote sensing applications in soil erosion mapping and monitoring. Remote Sens. Appl.: Soc. Environ. 9, 1-9.

Stewart, B., Wischmeier, W., Woolhiser, D., 1975. Control of Water Pollution from Cropland: Vol. 1, a Manual for Guideline Development, Vol. 2, an Overview. United States Department of Agriculture, USA.

Tengberg, A., Stocking, M., 1997. Erosion-Induced Loss in Soil Productivity and Its Impacts on Agricultural Production and Food Security. FAO/AGRITEX Expert Consultation on Integrated Soil Management for Sustainable 
Agriculture and Food Security in Southern and Eastern Africa, Harare, Zimbabwe, pp. 8-12.

Thornes, J.B., 1990. Vegetation and Erosion: Processes and Environments.

Vrieling, A., 2006. Satellite remote sensing for water erosion assessment: a review. Catena 65, 2-18.

Wischmeier, W.H., Smith, D.D., 1978. Predicting Rainfall Erosion Losses-A Guide to Conservation Planning. Predicting Rainfall Erosion Losses-A Guide to Conservation Planning.

Wynants, M., 2018. Pinpointing Areas of Increased Surface Erosion Risk Following Land Cover Changes in the Lake Manyara Catchment. Mendeley Data, Tanzania.

Zhang, H., Yang, Q., Li, R., Liu, Q., Moore, D., He, P., Ritsema, C.J., Geissen, V., 2013. Extension of a GIS procedure for calculating the RUSLE equation LS factor. Comput. Geosci. 52, 177-188.

Zhu, Z., Woodcock, C.E., 2014. Continuous change detection and classification of land cover using all available Landsat data. Remote Sens. Environ. 144, 152-171. 